\title{
Vascular endothelial growth factor gene polymorphisms and the risk of renal cell carcinoma: Evidence from eight case-control studies
}

\author{
Mancheng Gong ${ }^{1}$, Wenjing Dong${ }^{2}$, Zhirong Shi ${ }^{3}$, Shaopeng Qiu ${ }^{4}$, Runqiang Yuan ${ }^{1}$ \\ ${ }^{1}$ Department of Urology, Zhongshan Affiliated Hospital of Sun Yat-sen University, Zhongshan, Guangdong 528403, China \\ ${ }^{2}$ Department of Oncology, Zhongshan Affiliated Hospital of Sun Yat-sen University, Zhongshan, Guangdong 528403, China \\ ${ }^{3}$ Department of Pharmacy, The Second People's Hospital of Zhuhai, Zhuhai, Guangdong 519020, China \\ ${ }^{4}$ Department of Urology, The First Affiliated Hospital of Sun Yat-Sen University, Guangzhou, Guangdong 510080, China \\ Correspondence to: Runqiang Yuan, email: yuanrunqiang2013@163.com \\ Keywords: vascular endothelial growth factor, VEGF, renal cell carcinoma, gene polymorphism, meta-analysis \\ Received: August 20,2016 Accepted: December 01,2016 Published: December 27, 2016
}

\section{ABSTRACT}

Background: Vascular endothelial growth factor (VEGF) protein plays important role in renal cell carcinoma (RCC) development and progression. VEGF gene polymorphisms can alter the protein concentrations and might be associated with renal cell carcinoma risk. However, the results of studies investigating the association between VEGF polymorphisms and renal cell carcinoma risk are inconsistent. Thus, a meta-analysis was performed.

Methods: We selected eligible studies via electronic searches. Only high-quality studies were included based on specific inclusion criteria and the Newcastle-Ottawa Scale (NOS).

Results: Eight studies primarily focusing on seven polymorphisms were included in our meta-analysis. Our results showed dramatically high risks for renal cell carcinoma were found regarding most genetic models and alleles of the $+936 \mathrm{C} / \mathrm{T}$ polymorphism (except CT vs. CC). In addition, significant increased renal cell carcinoma risks were found regarding all genetic models and alleles of the $-2578 \mathrm{C} /$ A polymorphism. However, no significant associations were found between renal cell carcinoma risk and the $+1612 G / A,-460 T / C,-634 G / C,-405 G / C$ or $-1154 G / A$ polymorphisms.

Conclusions: Our meta-analysis indicates that the $+936 \mathrm{C} / \mathrm{T}$ and $-2578 \mathrm{C} / \mathrm{A}$ polymorphisms of VEGF are associated with an increased risk for renal cell carcinoma. Additional rigorous analytical studies are needed to confirm our results.

\section{INTRODUCTION}

Approximately 337,860 cases of renal cell carcinoma (RCC) are diagnosed annually, and nearly 143,406 patients die from this cancer each year worldwide [1]. RCC is the third most common genitourinary malignancy. Moreover, both the incidence and mortality rates of RCC have steadily increased over the past several years [2]. The etiology of RCC is complex and multifactorial, and it involves multiple environmental and genetic factors $[3,4]$. Although an increasing number of studies have been performed on the etiology of RCC, the real causes of this cancer remain unclear. Previous studies have shown that many environmental factors such as cigarette smoking, alcohol drinking, occupational exposure to chemicals, hypertension and low frequencies of physical activity increase the risk of RCC [5-7]. Although many people are exposed to these risk factors during their lifetime, only a few people develop RCC. This finding suggests that genetic susceptibility plays a critical role in the etiology of this disease $[8,9]$.

Vascular endothelial growth factor (VEGF) is an important pro-angiogenic growth factor, and it is one of the most potent endothelial cell mitogens [10,11]. VEGF 
plays a critical role in regulating the egress of the plasma proteins and cells that directly and indirectly stimulate angiogenesis [12]. Some research has indicated that the expression of VEGF affects tumor growth and metastasis, whereas the inhibition of VEGF signaling suppresses both tumor-induced angiogenesis and tumor growth [13]. The $V E G F$ gene is located at chromosome $6 \mathrm{p} 21.3$ and consists of 8 exons. At least 30 single nucleotide polymorphisms (SNPs) exist in this gene [14] and some experimental studies have shown that certain SNPs can affect gene expression and change gene function [15].

Recently, numerous studies have been performed to evaluate the association between $V E G F$ polymorphisms and $\mathrm{RCC}$ risk in diverse populations; however, the results of these studies conflict. To examine the association between $V E G F$ polymorphisms and RCC risk, we performed a meta-analysis of all eligible published data up to June 5, 2016.

\section{RESULTS}

\section{Study characteristics}

We performed a literature search, and 286 potentially relevant publications were identified. After screening the title and abstract of each study, 277 studies were excluded because they did not involve both VEGF polymorphisms and $\mathrm{RCC}$ risk. After the subsequent data extraction, one study was excluded because it lacked controls [16].
Finally, we obtained 8 relevant articles [17-24] that examined the association between $V E G F$ polymorphisms and RCC risk (Figure 1); the data extracted from the articles are summarized in Table 1 . All of the included studies were evaluated using the Newcastle-Ottawa Scale (NOS) and were of high quality (Table 2). Of the 8 studies, 6 focused on the $+936 \mathrm{C} / \mathrm{T}$ polymorphism (rs3025039), 5 discussed -2578C/A (rs699947), 3 discussed +1612G/A (rs10434), -460T/C (rs833061) and -634G/C (rs2010963), and 2 studies examined both $-405 \mathrm{G} / \mathrm{C}$ (rs2010963) and $-1154 \mathrm{G} / \mathrm{A}$ (rs1570360). All of the included articles (excluding Shen et al.[20] and Lu et al. [21]) were case control studies, and their genotypic distributions across the controls followed Hardy-Weinberg Equilibrium (HWE).

\section{$+936 \mathrm{C} / \mathrm{T}(\mathrm{rs3025039})$}

Six studies [17-22] including 1,445 cases and 2,337 controls examining the $+936 \mathrm{C} / \mathrm{T}$ (rs3025039) polymorphism were pooled. Overall, significant increased cancer risks were observed in most genetic models and alleles (TT vs. CC: odds ratio $[\mathrm{OR}]=1.38,95 \%$ confidence intervals $[\mathrm{CIs}]=1.11-1.72, P=0.004, I^{2}=25.3$, Figure 2A; TT vs. $\mathrm{CT}+\mathrm{CC}: \mathrm{OR}=1.28,95 \% \mathrm{CIs}=1.04-1.57, P=0.019$, $I^{2}=0.0$, Figure $2 \mathrm{~B}$; TT $+\mathrm{CT}$ vs. $\mathrm{CC}: \mathrm{OR}=1.21,95 \%$ $\mathrm{CIs}=1.05-1.39, P=0.010, I^{2}=38.7$, Figure $2 \mathrm{C}$; T vs. $\mathrm{C}$ : $\mathrm{OR}=1.20,95 \% \mathrm{CIs}=1.07-1.34, P=0.001, I^{2}=32.0$, Figure 2E) except $\mathrm{CT}$ vs. $\mathrm{CC}(\mathrm{OR}=1.17,95 \% \mathrm{CIs}=1.00-1.37$, $P=0.056, I^{2}=25.3$, Figure 2D).

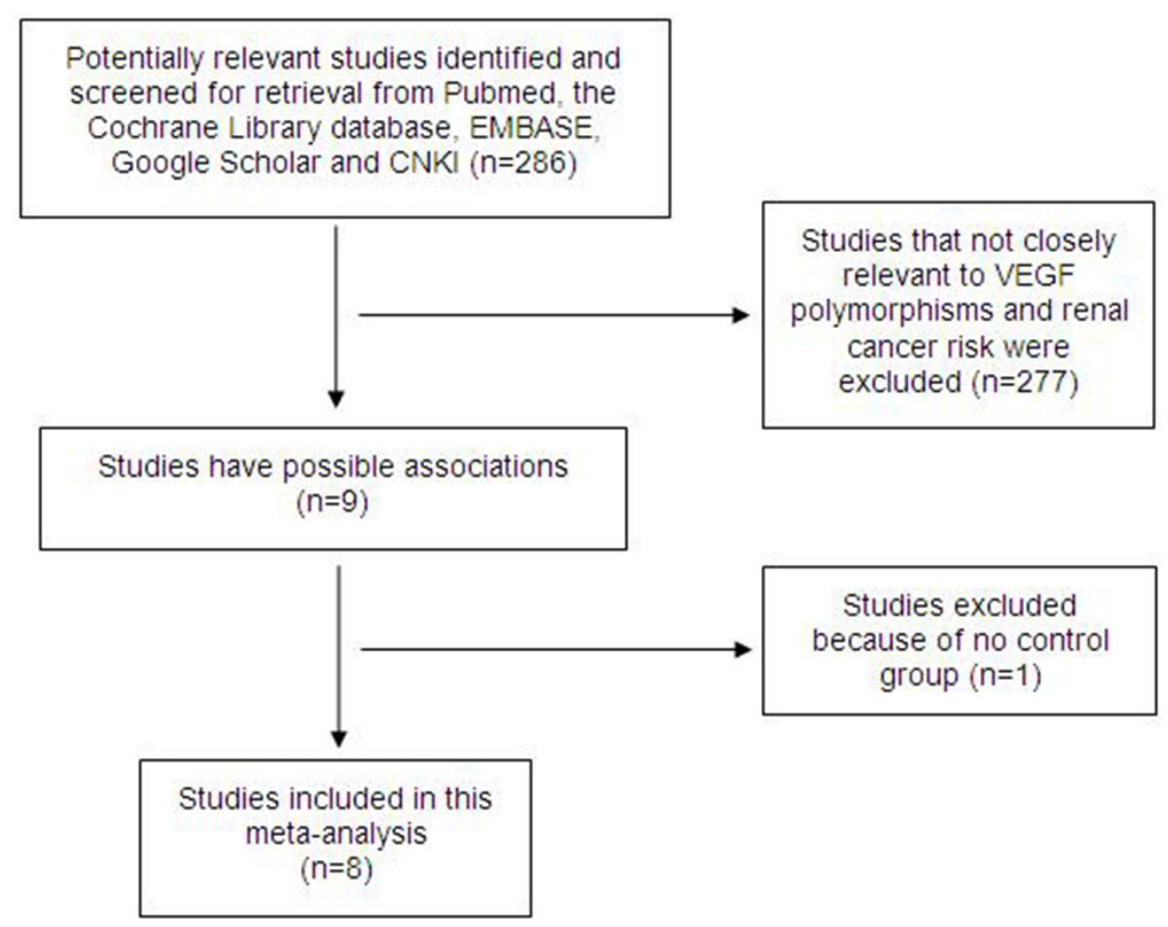

Figure 1: Flow diagram of the study selection. 
Table 1: Characteristics of eligible studies in the meta-analysis of $V E G F$ polymorphisms and RCC risk

\begin{tabular}{|c|c|c|c|c|c|c|c|c|c|c|c|c|c|}
\hline Author & Year & $\begin{array}{l}\text { Quality } \\
\text { scores }\end{array}$ & Ethnicity & Design & $\begin{array}{l}\text { Cases } \\
\text { total }\end{array}$ & $\mathrm{CC}$ & CT & TT & $\begin{array}{c}\text { Controls } \\
\text { total }\end{array}$ & $\mathrm{CC}$ & CT & TT & $P$ HWE \\
\hline \multicolumn{14}{|l|}{$\begin{array}{l}+936 \mathrm{C} / \mathrm{T} \\
(\mathrm{rs3025039})\end{array}$} \\
\hline Abe $A[17]$ & 2002 & 5 & Asian & HB & 145 & 97 & 41 & 7 & 145 & 90 & 52 & 3 & 0.146 \\
\hline $\begin{array}{l}\text { Bruyère } \\
\mathrm{F}[18]\end{array}$ & 2010 & 5 & Caucasian & $\mathrm{PB}$ & 47 & 29 & 17 & 1 & 196 & 141 & 53 & 2 & 0.218 \\
\hline $\begin{array}{l}\text { Sáenz- } \\
\text { López P[19] }\end{array}$ & 2013 & 6 & Caucasian & $\mathrm{PB}$ & 215 & 156 & 57 & 2 & 280 & 200 & 73 & 7 & 0.912 \\
\hline $\begin{array}{l}\text { Shen } \\
\text { BL[20] }\end{array}$ & 2015 & 5 & Asian & $\mathrm{HB}$ & 360 & 224 & 81 & 55 & 359 & 240 & 73 & 46 & 0.000 \\
\hline Lu GJ[21] & 2015 & 5 & Asian & HB & 412 & 262 & 91 & 59 & 825 & 554 & 166 & 105 & 0.000 \\
\hline Xian W[22] & 2015 & 5 & Asian & HB & 266 & 70 & 127 & 69 & 532 & 196 & 236 & 100 & 0.056 \\
\hline $\begin{array}{l}-2578 C / A \\
\text { (rs699947) }\end{array}$ & & & & & $\begin{array}{l}\text { Cases } \\
\text { total }\end{array}$ & $\mathrm{CC}$ & $\mathbf{C A}$ & $\mathbf{A A}$ & $\begin{array}{c}\text { Controls } \\
\text { total }\end{array}$ & $\mathrm{CC}$ & CA & $\mathbf{A A}$ & \\
\hline Ajaz S[23] & 2011 & 5 & Asian & NA & 143 & 30 & 81 & 32 & 106 & 44 & 41 & 21 & 0.053 \\
\hline $\begin{array}{l}\text { Sáenz- } \\
\text { López P[19] }\end{array}$ & 2013 & 6 & Caucasian & $\mathrm{PB}$ & 216 & 54 & 114 & 48 & 272 & 77 & 142 & 53 & 0.388 \\
\hline $\begin{array}{l}\text { Shen } \\
\text { BL[20] }\end{array}$ & 2015 & 5 & Asian & $\mathrm{HB}$ & 360 & 150 & 149 & 61 & 360 & 178 & 141 & 41 & 0.111 \\
\hline Lu GJ[21] & 2015 & 5 & Asian & $\mathrm{HB}$ & 412 & 171 & 174 & 67 & 824 & 397 & 332 & 95 & 0.047 \\
\hline Xian W[22] & 2015 & 5 & Asian & HB & 266 & 99 & 119 & 48 & 532 & 243 & 225 & 64 & 0.287 \\
\hline $\begin{array}{l}+1612 G / A \\
(r s 10434)\end{array}$ & & & & & $\begin{array}{l}\text { Cases } \\
\text { total }\end{array}$ & GG & GA & $\mathbf{A A}$ & $\begin{array}{c}\text { Controls } \\
\text { total }\end{array}$ & GG & GA & $\mathbf{A A}$ & \\
\hline Abe A[17] & 2002 & 5 & Asian & $\mathrm{HB}$ & 145 & 113 & 31 & 1 & 145 & 109 & 33 & 3 & 0.788 \\
\hline $\begin{array}{l}\text { Shen } \\
\text { BL[18] }\end{array}$ & 2015 & 5 & Asian & HB & 361 & 152 & 170 & 39 & 360 & 166 & 164 & 30 & 0.234 \\
\hline Lu GJ[21] & 2015 & 5 & Asian & $\mathrm{HB}$ & 412 & 172 & 191 & 49 & 825 & 365 & 375 & 85 & 0.431 \\
\hline $\begin{array}{l}-460 \mathrm{~T} / \mathrm{C} \\
\text { (rs833061) }\end{array}$ & & & & & $\begin{array}{l}\text { Cases } \\
\text { total }\end{array}$ & $\mathbf{T T}$ & $\mathbf{T C}$ & $\mathrm{CC}$ & $\begin{array}{c}\text { Controls } \\
\text { total }\end{array}$ & $\mathbf{T T}$ & TC & $\mathrm{CC}$ & \\
\hline $\begin{array}{l}\text { Bruyère } \\
F[18]\end{array}$ & 2010 & 5 & Caucasian & PB & 49 & 19 & 29 & 1 & 202 & 47 & 109 & 46 & 0.260 \\
\hline $\begin{array}{l}\text { Sáenz- } \\
\text { López P[19] }\end{array}$ & 2013 & 6 & Caucasian & PB & 216 & 56 & 111 & 49 & 273 & 77 & 138 & 58 & 0.793 \\
\hline Lu GJ[21] & 2015 & 5 & Asian & HB & 412 & 228 & 93 & 91 & 824 & 513 & 168 & 143 & 0.000 \\
\hline $\begin{array}{l}-634 G / C \\
(r s 2010963)\end{array}$ & & & & & $\begin{array}{l}\text { Cases } \\
\text { total }\end{array}$ & GG & GC & $\mathrm{CC}$ & $\begin{array}{c}\text { Controls } \\
\text { total }\end{array}$ & GG & $\mathrm{C}$ & $\mathrm{CC}$ & \\
\hline $\begin{array}{l}\text { Shen } \\
\text { BL[20] }\end{array}$ & 2015 & 5 & Asian & $\mathrm{HB}$ & 360 & 121 & 170 & 69 & 360 & 134 & 163 & 63 & 0.273 \\
\hline Lu GJ[21] & 2015 & 5 & Asian & $\mathrm{HB}$ & 412 & 139 & 194 & 79 & 824 & 299 & 377 & 148 & 0.127 \\
\hline Xian W[22] & 2015 & 5 & Asian & HB & 266 & 30 & 132 & 104 & 532 & 49 & 256 & 227 & 0.053 \\
\hline
\end{tabular}

(Continued) 


\begin{tabular}{|c|c|c|c|c|c|c|c|c|c|c|c|c|c|}
\hline Author & Year & $\begin{array}{c}\text { Quality } \\
\text { scores }\end{array}$ & Ethnicity & Design & $\begin{array}{c}\text { Cases } \\
\text { total }\end{array}$ & $\mathrm{CC}$ & CT & TT & $\begin{array}{c}\text { Controls } \\
\text { total }\end{array}$ & $\mathrm{CC}$ & CT & TT & $P$ HWE \\
\hline $\begin{array}{l}-405 G / C \\
(\mathrm{rs} 2010963)\end{array}$ & & & & & $\begin{array}{c}\text { Cases } \\
\text { total }\end{array}$ & GG & GC & $\mathrm{CC}$ & $\begin{array}{c}\text { Controls } \\
\text { total }\end{array}$ & GG & GC & $\mathrm{CC}$ & \\
\hline $\begin{array}{l}\text { Bruyère } \\
\text { F[18] }\end{array}$ & 2010 & 5 & Caucasian & PB & 48 & 15 & 25 & 8 & 198 & 86 & 92 & 20 & 0.522 \\
\hline $\begin{array}{c}\text { Sáenz- } \\
\text { López P[19] }\end{array}$ & 2013 & 6 & Caucasian & PB & 214 & 101 & 93 & 20 & 279 & 129 & 118 & 32 & 0.528 \\
\hline $\begin{array}{l}-1154 G / A \\
(\text { rs1570360) }\end{array}$ & & & & & $\begin{array}{c}\text { Cases } \\
\text { total }\end{array}$ & GG & GA & $\mathbf{A A}$ & $\begin{array}{c}\text { Controls } \\
\text { total }\end{array}$ & GG & GA & $\mathbf{A A}$ & \\
\hline $\begin{array}{l}\text { Ricketts } \\
\text { C[24] }\end{array}$ & 2009 & 6 & Caucasian & PB & 324 & 134 & 143 & 47 & 314 & 146 & 130 & 38 & 0.281 \\
\hline $\begin{array}{l}\text { Bruyère } \\
\text { F[18] }\end{array}$ & 2010 & 5 & Caucasian & PB & 49 & 27 & 17 & 5 & 202 & 94 & 83 & 25 & 0.322 \\
\hline
\end{tabular}

HB, hospital-based controls; HWE, Hardy-Weinberg equilibrium.

Table 2: Quality assessment based on the Newcastle-Ottawa Scale of studies included in this meta-analysis ${ }^{a}$

\begin{tabular}{|c|c|c|c|c|c|c|c|c|c|c|}
\hline Author & Year & $\begin{array}{c}\text { Adequate } \\
\text { definition } \\
\text { of case }\end{array}$ & $\begin{array}{l}\text { Representativeness } \\
\quad \text { of cases }\end{array}$ & $\begin{array}{c}\text { Selection } \\
\text { of } \\
\text { control }\end{array}$ & $\begin{array}{l}\text { Definition } \\
\text { of control }\end{array}$ & $\begin{array}{l}\text { Control } \\
\text { for } \\
\text { important } \\
\text { factor or } \\
\text { additional } \\
\text { factor }^{b}\end{array}$ & $\begin{array}{c}\text { Exposure } \\
\text { assessment }\end{array}$ & $\begin{array}{c}\text { Same } \\
\text { method of } \\
\text { ascertainment } \\
\text { for cases and } \\
\text { controls }\end{array}$ & $\begin{array}{l}\text { Nonresponse } \\
\text { rate }\end{array}$ & $\begin{array}{c}\text { Total } \\
\text { quality } \\
\text { scores }\end{array}$ \\
\hline $\begin{array}{l}\text { Abe } \\
\text { A[17] }\end{array}$ & 2002 & $\star$ & $\star$ & & $\star$ & $\star$ & & $\star$ & & 5 \\
\hline $\begin{array}{l}\text { Bruyère } \\
F[18]\end{array}$ & 2010 & $\star$ & $\star$ & $\star$ & $\star$ & & & $\star$ & & 5 \\
\hline $\begin{array}{l}\text { Sáenz- } \\
\text { López } \\
\text { P[19] }\end{array}$ & 2013 & $\star$ & $\star$ & $\star$ & $\star$ & $\star$ & & $\star$ & & 6 \\
\hline $\begin{array}{l}\text { Shen } \\
\text { BL[20] }\end{array}$ & 2015 & $\star$ & $\star$ & & $\star$ & $\star$ & & $\star$ & & 5 \\
\hline $\begin{array}{l}\mathrm{Lu} \\
\mathrm{GJ}[21]\end{array}$ & 2015 & $\star$ & $\star$ & & $\star$ & $\star$ & & $\star$ & & 5 \\
\hline $\begin{array}{l}\text { Xian } \\
\text { W[22] }\end{array}$ & 2015 & $\star$ & $\star$ & & $\star$ & $\star$ & & $\star$ & & 5 \\
\hline $\begin{array}{l}\text { Ajaz } \\
\mathrm{S}[23]\end{array}$ & 2011 & $\star$ & $\star$ & & $\star$ & $\star$ & & $\star$ & & 5 \\
\hline $\begin{array}{l}\text { Ricketts } \\
\text { C[24] }\end{array}$ & 2009 & $\star$ & $\star$ & $\star$ & $\star$ & $\star$ & & $\star$ & & 6 \\
\hline
\end{tabular}

${ }^{a}$ A study can be awarded a maximum of one star for each numbered item except for the item Control for important factor or additional factor.

${ }^{\mathrm{b}}$ A maximum of two stars can be awarded for Control for important factor or additional factor.

\section{$-2578 \mathrm{C} / \mathrm{A}($ rs699947)}

Five articles [19-25] including 1,397 cases and 2,094 controls examined the relationship between the $-2578 \mathrm{C} / \mathrm{A}$ (rs699947) polymorphism and RCC risk.
Remarkably, significant associations were found in all genetic models (AA vs. $\mathrm{CC}$ : $\mathrm{OR}=1.69,95 \% \mathrm{CIs}=1.37$ 2.07, $P=0.000, I^{2}=0.0$, Figure $3 \mathrm{~A}$; AA vs. $\mathrm{CA}+\mathrm{CC}$ : $\mathrm{OR}=1.43,95 \% \mathrm{CIs}=1.19-1.73, P=0.000, I^{2}=0.0$, Figure 3B; $\mathrm{AA}+\mathrm{CA}$ vs. $\mathrm{CC}: \mathrm{OR}=1.39,95 \% \mathrm{CIs}=1.21-1.61$, 
$P=0.000, I^{2}=34.8$, Figure $3 \mathrm{C}$; CA vs. $\mathrm{CC}: \mathrm{OR}=1.31,95 \%$ CIs $=1.12-1.52, P=0.001, I^{2}=47.1$, Figure $\left.3 \mathrm{D}\right)$, and also the A vs. $\mathrm{C}$ allele $(\mathrm{OR}=1.31,95 \% \mathrm{CIs}=1.19-1.45, P=0.000$, $I^{2}=0.0$, Figure $\left.3 \mathrm{E}\right)$.

\section{$+1612 \mathrm{G} / \mathrm{A}(\mathrm{rs10434}),-460 \mathrm{~T} / \mathrm{C}(\mathrm{rs833061})$ and $-634 \mathrm{G} / \mathrm{C}$ (rs2010963)}

Three studies discussed the $+1612 \mathrm{G} / \mathrm{A}$ (rs 10434) [17, 20, 21], -460T/C (rs833061) [18, 19, 21] and -634G/ C (rs2010963) [20-22] polymorphisms. The numbers of participants in these studies were 918, 677 and 1,038 cases and 1,330, 1,299 and 1,716 controls, respectively. Unfortunately, no significant associations were found between RCC risks and in any genetic model or allele of these three polymorphisms.

\section{$-405 G / C$ (rs2010963) and -1154G/A (rs1570360)}

We also investigated the $-405 \mathrm{G} / \mathrm{C}$ (rs2010963) [18, 19] and -1154G/A (rs1570360) [18, 24] polymorphisms, both of which were examined in two studies including
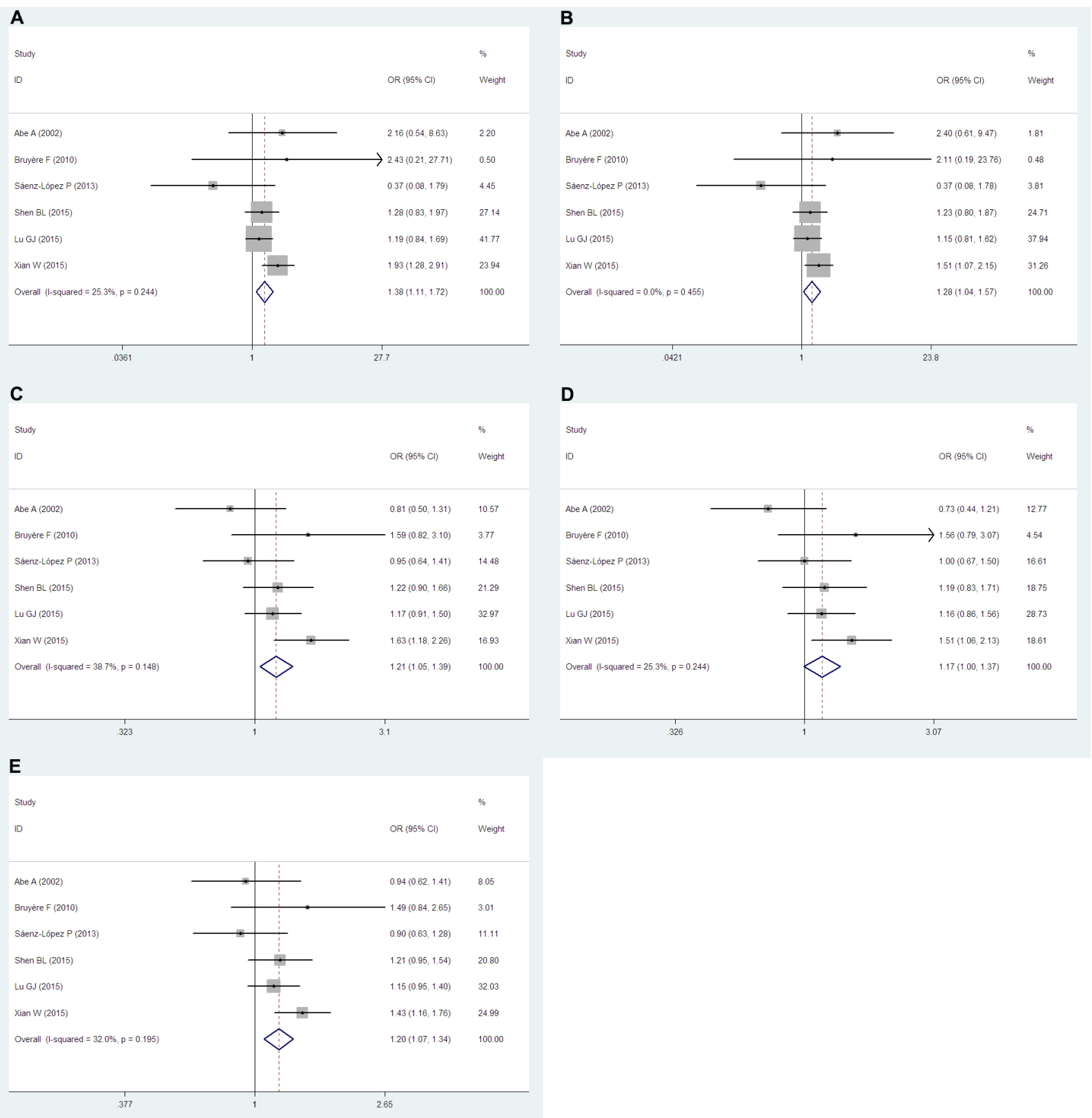

Figure 2: Forest plots of the +936C/T (rs3025039) polymorphism and RCC risk. The squares and horizontal lines correspond to the study-specific ORs and $95 \%$ CIs. The areas of the squares reflect the study-specific weights (which was the inverse of the variance). The diamonds represent the pooled ORs and $95 \%$ CIs. 
262 and 373 cases and 477 and 516 controls, respectively. However, we did not identify any association between RCC risk and either the $-405 \mathrm{G} / \mathrm{C}$ (rs2010963) or $-1154 \mathrm{G} /$ A (rs1570360) polymorphism.

\section{Sensitivity analyses}

Hardy-Weinberg disequilibrium was observed in two studies (Shen et al.[20] and Lu et al. [21]). For $+936 \mathrm{C} / \mathrm{T}$ (rs3025039) polymorphism, our sensitivity analyses results indicated that exclusion of the aforementioned studies did not change the results for all the genetic models and allele (data not shown). In addition, for $-2578 \mathrm{C} / \mathrm{A}$ (rs699947) polymorphism, the sensitivity analyses results for all the genetic models and allele did not change either when excluding the study of Lu et al. [21] (data not shown).

\section{A}

Study

Aiaz $S$ (2011)

Sảenz-López P (2013)

Shen BL (2015)

LU GJ (2015)

Xian W (2015)

Overal (l-squared $=0.0 \%, \mathrm{p}=0.772$

.218

C

study

ID

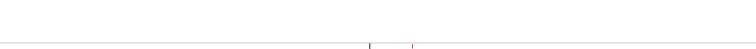

Ajaz S (2011)

Sáenz-López P (2013)

Shen BL (2015)

LU GJ (2015)

Xian W (2015)

Overall (1-squared $=348 \%, p=0.189$
OR $(95 \% \mathrm{Cl}) \quad$ Weicht

$223(1.09 .4 .59)-732$

$1.64(1.14,2.35) \quad 32.82$

$1.84(1.18,2.86) \quad 20.58$

$1.69(1.37,2.07) \quad 100.00$

4.59
$1.29(0.77,218)-18.9$

$177(112,277)-2109$
B

Study

ID

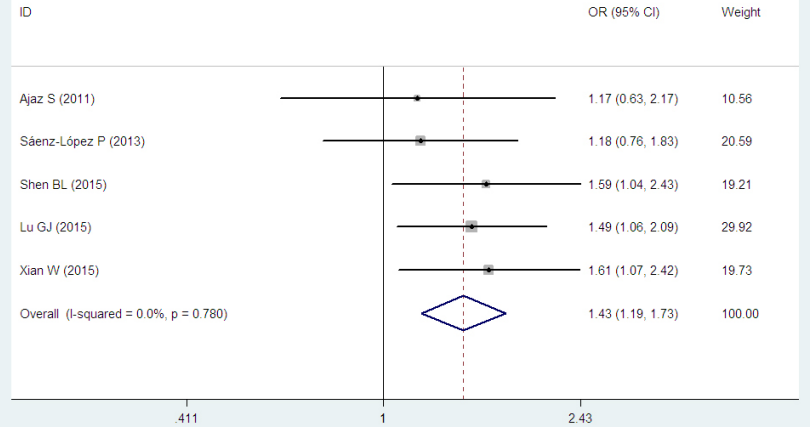

D

study

10

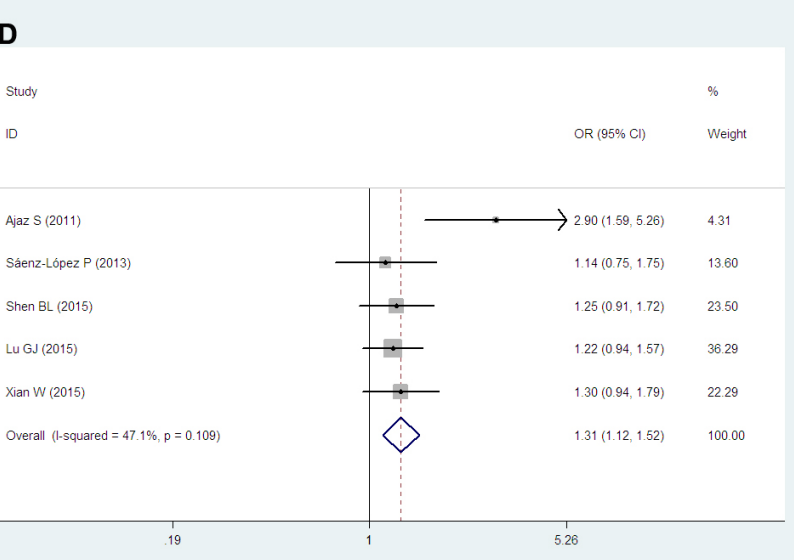

$\mathrm{E}$

Study

Stud
ID

ID $\quad$ OR (95\% Cl) Weight

\begin{tabular}{l|l|ll} 
Ajaz S (2011) & & & \\
\hline & & & \\
$1.60(1.11,2.29)$ & 7.15
\end{tabular}

Ajaz S (2011)
Sáenz-López P (2013)

Shen BL (2015)

LuGJ (2015)

Xian W (2015)

Overal (l-squared $=0.0 \%, p=0.603$

436

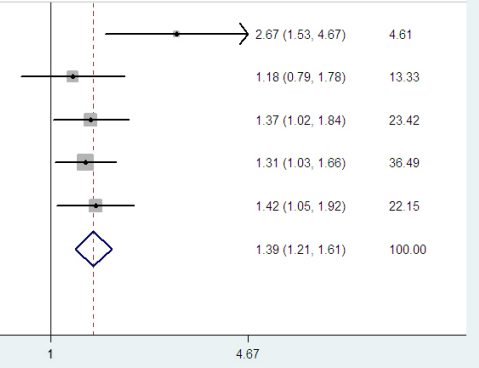

Figure 3: Forest plots of the $-2578 C / A$ (rs699947) polymorphism and RCC risk. The squares and horizontal lines correspond to the study-specific ORs and $95 \%$ CIs. The areas of the squares reflect the study-specific weights (which were the inverse of the variance). Diamonds represent the pooled ORs and $95 \%$ CIs. 


\section{Publication bias}

Except for the -405G/C (rs2010963) and -1154G/A (rs1570360) polymorphisms, we used both funnel plots and Egger's test to assess the publication bias of each genetic model and allele. Our results did not show a publication bias for most of the genetic models and alleles (Supplementary Figure 1-2 showed the funnel plots of $+936 \mathrm{C} / \mathrm{T}$ and $-2578 \mathrm{C} / \mathrm{A}$ polymorphisms, respectively), except regarding $\mathrm{CC}$ vs. CT+TT of the $-460 \mathrm{~T} / \mathrm{C}$ (rs833061) polymorphism $(P=0.038)$.

\section{DISCUSSION}

VEGF, a growth factor that regulates angiogenesis and is involved in promoting endothelial cell proliferation [25]. VEGF protein likely plays an important role in the development and progression of cancer. Researchers have found that the expression of $V E G F$ is significantly related to tumor stage, tumor size, and nuclear grade in patients with clear cell RCC [26]. In addition, the overexpression of $V E G F$ has been detected in the vast majority of RCC tissues [27]. Currently, VEGF inhibition is a therapy for RCC [28]. However, the $V E G F$ gene is highly polymorphic [29] and several functional SNPs in the $V E G F$ gene alter the expression of the VEGF protein, thereby affecting tumor growth and progression. Recent studies have investigated the association between SNPs in the $V E G F$ gene and the risk of RCC. However, these results are controversial. Thus, we conducted this meta-analysis to discuss the relationship between $V E G F$ polymorphisms and RCC risk.

Zhang et al. [30] previously performed a metaanalysis that observed the association between $V E G F$ polymorphisms and RCC risk. However, the author only reviewed 5 studies. In contrast, our meta-analysis included 8 relevant published studies. Moreover, our meta-analysis included many more cases and controls than the prior meta-analysis. In addition, we evaluated the quality of studies using the NOS. All of the included studies met high-quality standards, whereas the prior meta-analysis did not conduct any quality assessment. Thus, our meta-analysis is a more convincing and detailed evaluation compared with the prior study. Overall, we found that significant associations exist between $V E G F$ polymorphisms and RCC risk (all of our results are summarized in Table 3 ). Specifically, most genetic models and alleles found high risks of RCC regarding the $+936 \mathrm{C} / \mathrm{T}$ (rs3025039) polymorphism. To the best of our knowledge, our study is the first meta-analysis to report that the $+936 \mathrm{C} / \mathrm{T}$ (rs3025039) polymorphism of $V E G F$ can increase the risk of RCC. The $+936 \mathrm{C} / \mathrm{T}$ (rs3025039) polymorphism is located in the $3^{\prime}$-UTR and likely associated with obviously increased serum VEGF levels [31], which are related to tumor stage, tumor size, and nuclear grade. Interestingly, according to the results of
Krippl P [32], the carriers of a $+936 \mathrm{~T}$ allele had significant decreased risks of breast cancer and lower serum VEGF levels, which is opposite with our results. The reason of this discrepancy may be the tumor heterogeneity. Tumor heterogeneity is complex in many levels, including interdisease, intertumor, intratumor and tumormicroenvironment heterogeneity, etc. [33]. Furthermore, significant RCC risks were found in all genetic models and alleles of the -2578C/A (rs699947) polymorphism, whereas the prior meta-analysis only found increased RCC risks for the AA vs. CC genetic model and the A vs. C allele. Currently, several studies have reported that the $-2578 \mathrm{C} / \mathrm{A}$ (rs699947) polymorphism in the promoter region plays an influential role regarding plasma VEGF levels $[34,35]$. However, no significant associations were found between RCC risk and the $+1612 \mathrm{G} / \mathrm{A}$ (rs10434), $-460 \mathrm{~T} / \mathrm{C}(\mathrm{rs} 833061),-634 \mathrm{G} / \mathrm{C}$ (rs2010963), $-405 \mathrm{G} / \mathrm{C}$ (rs2010963) or -1154G/A (rs1570360) polymorphisms. All of the characteristics and results of the present study were compared with the former meta-analysis and summarized in Table 4 .

Certain limitations of this meta-analysis should be acknowledged. First, because our study only considered published articles, a publication bias might exist. However, the publication bias was only found for the $\mathrm{CC}$ vs. CT+TT of $-460 \mathrm{~T} / \mathrm{C}$ (rs833061) polymorphism. The statistical results of the funnel plot and Egger's test support this finding. Second, the heterogeneities among certain genetic models and alleles were significant. The reasons underlying these heterogeneities included the source of the controls, the study design and differences in genetic backgrounds. Third, the control sample of two articles were in Hardy-Weinberg disequilibrium, however, all the results of $+936 \mathrm{C} / \mathrm{T}$ (rs3025039) and $-2578 \mathrm{C} / \mathrm{A}$ (rs699947) polymorphisms did not change significantly after sensitivity analyses. Fourth, as the most of the cases of $+936 \mathrm{C} / \mathrm{T}$ and $-2578 \mathrm{C} / \mathrm{A}$ polymorphisms were from Asians, so our results of these two SNPs may not represent Caucasians. Finally, because of the use of unadjusted data, potential confounds such as age, sex and residence might also have affected the effect estimates. Thus, a more precise and large scale evaluation based on adjusted data is needed.

In summary, our meta-analysis suggests that the $+936 \mathrm{C} / \mathrm{T}$ (rs3025039) and -2578C/A (rs699947) polymorphisms of $V E G F$ are associated with increased risks for RCC. However, no significant RCC risks were obtained regarding the $+1612 \mathrm{G} / \mathrm{A}$ ( $\mathrm{rs} 10434),-460 \mathrm{~T} / \mathrm{C}$ (rs833061), -634G/C (rs2010963), -405G/C (rs2010963) or $-1154 \mathrm{G} / \mathrm{A}$ (rs1570360) polymorphisms. To the best of our knowledge, this meta-analysis is the first to report that the $+936 \mathrm{C} / \mathrm{T}$ (rs3025039) polymorphism can increase the risk of RCC. Larger and more rigorous analytical studies are required to confirm our results and evaluate the gene-environment interactions with regard to $\mathrm{RCC}$ risk. 
Table 3: Summary of meta-analysis of $V E G F$ polymorphisms and RCC risk

\begin{tabular}{|c|c|c|c|c|c|c|c|c|}
\hline Polymorphism & $\begin{array}{l}\text { No. of } \\
\text { studies }\end{array}$ & $\begin{array}{l}\text { No. of } \\
\text { cases }\end{array}$ & $\begin{array}{c}\text { No. of } \\
\text { controls }\end{array}$ & Contrast & OR $(95 \%$ CI $)$ & $\begin{array}{c}\text { Statistical } \\
\text { method }\end{array}$ & $\mathbf{I}^{2 \%} \%$ & $P$-value \\
\hline$+936 \mathrm{C} / \mathrm{T}$ & 6 & 1,445 & 2,337 & TT vs. CC & $1.38(1.11-1.72)$ & Fixed & 25.3 & 0.004 \\
\hline \multirow[t]{4}{*}{ (rs3025039) } & & & & TT vs. $\mathrm{CT}+\mathrm{CC}$ & $1.28(1.04-1.57)$ & Fixed & 0.0 & 0.019 \\
\hline & & & & TT+CT vs. CC & $1.21(1.05-1.39)$ & Fixed & 38.7 & 0.010 \\
\hline & & & & CT vs. CC & $1.17(1.00-1.37)$ & Fixed & 25.3 & 0.056 \\
\hline & & & & T vs. C & $1.20(1.07-1.34)$ & Fixed & 32.0 & 0.001 \\
\hline$-2578 \mathrm{C} / \mathrm{A}$ & 5 & 1,397 & 2,094 & AA vs. CC & $1.69(1.37-2.07)$ & Fixed & 0.0 & 0.000 \\
\hline \multirow[t]{4}{*}{ (rs699947) } & & & & $\mathrm{AA}$ vs. $\mathrm{CA}+\mathrm{CC}$ & $1.43(1.19-1.73)$ & Fixed & 0.0 & 0.000 \\
\hline & & & & $\mathrm{AA}+\mathrm{CA}$ vs. $\mathrm{CC}$ & $1.39(1.21-1.61)$ & Fixed & 34.8 & 0.000 \\
\hline & & & & CA vs. CC & $1.31(1.12-1.52)$ & Fixed & 47.1 & 0.001 \\
\hline & & & & A vs. C & $1.31(1.19-1.45)$ & Fixed & 0.0 & 0.000 \\
\hline$+1612 \mathrm{G} / \mathrm{A}$ & 3 & 918 & 1,330 & AA vs. GG & $1.25(0.92-1.71)$ & Fixed & 0.0 & 0.159 \\
\hline \multirow[t]{4}{*}{ (rs10434) } & & & & AA vs. GA+GG & $1.20(0.89-1.61)$ & Fixed & 0.0 & 0.234 \\
\hline & & & & $\mathrm{AA}+\mathrm{GA}$ vs. GG & $1.10(0.92-1.31)$ & Fixed & 0.0 & 0.280 \\
\hline & & & & GA vs. GG & $1.08(0.90-1.30)$ & Fixed & 0.0 & 0.423 \\
\hline & & & & A vs. G & $1.10(0.96-1.25)$ & Fixed & 0.0 & 0.178 \\
\hline$-460 \mathrm{~T} / \mathrm{C}$ & 3 & 677 & 1,299 & CC vs. TT & $0.88(0.38-2.01)$ & Random & 80.6 & 0.758 \\
\hline \multirow[t]{4}{*}{ (rs833061) } & & & & $\mathrm{CC}$ vs. TC+TT & $0.93(0.47-1.84)$ & Random & 77.9 & 0.830 \\
\hline & & & & $\mathrm{CC}+\mathrm{TC}$ vs. TT & $0.98(0.61-1.58)$ & Random & 75.5 & 0.928 \\
\hline & & & & TC vs. TT & $1.12(0.89-1.41)$ & Fixed & 31.0 & 0.343 \\
\hline & & & & C vs. T & $0.92(0.58-1.46)$ & Random & 87.9 & 0.720 \\
\hline$-634 \mathrm{G} / \mathrm{C}$ & 3 & 1,038 & 1,716 & CC vs. GG & $1.07(0.84-1.35)$ & Fixed & 16.4 & 0.581 \\
\hline \multirow[t]{4}{*}{ (rs2010963) } & & & & $\mathrm{CC}$ vs. $\mathrm{GC}+\mathrm{GG}$ & $1.00(0.83-1.20)$ & Fixed & 0.0 & 1.000 \\
\hline & & & & $\mathrm{CC}+\mathrm{GC}$ vs. $\mathrm{GG}$ & $1.09(0.91-1.30)$ & Fixed & 0.0 & 0.370 \\
\hline & & & & GC vs. GG & $1.08(0.89-1.31)$ & Fixed & 0.0 & 0.429 \\
\hline & & & & C vs. G & $1.03(0.92-1.16)$ & Fixed & 27.7 & 0.571 \\
\hline$-405 \mathrm{G} / \mathrm{C}$ & 2 & 262 & 477 & CC vs. GG & $1.26(0.45-3.51)$ & Random & 68.4 & 0.661 \\
\hline \multirow[t]{4}{*}{ (rs2010963) } & & & & $\mathrm{CC}$ vs. $\mathrm{GC}+\mathrm{GG}$ & $1.11(0.51-2.41)$ & Random & 54.5 & 0.796 \\
\hline & & & & $\mathrm{CC}+\mathrm{GC}$ vs. $\mathrm{GG}$ & $1.18(0.70-2.01)$ & Random & 52.5 & 0.536 \\
\hline & & & & GC vs. GG & $1.11(0.80-1.55)$ & Fixed & 13.0 & 0.532 \\
\hline & & & & C vs. G & $1.14(0.72-1.79)$ & Random & 67.0 & 0.584 \\
\hline$-1154 \mathrm{G} / \mathrm{A}$ & 2 & 373 & 516 & AA vs. GG & $1.19(0.77-1.84)$ & Fixed & 19.9 & 0.435 \\
\hline \multirow[t]{4}{*}{ (rs1570360) } & & & & AA vs. GA+GG & $1.14(0.76-1.73)$ & Fixed & 0.0 & 0.528 \\
\hline & & & & $\mathrm{AA}+\mathrm{GA}$ vs. GG & $1.00(0.59-1.69)$ & Random & 58.1 & 0.994 \\
\hline & & & & GA vs. GG & $1.08(0.80-1.46)$ & Fixed & 45.3 & 0.611 \\
\hline & & & & A vs. $G$ & $1.01(0.68-1.51)$ & Random & 57.1 & 0.948 \\
\hline
\end{tabular}


Table 4: Characteristics and results of the present study compared with the previous meta-analysis

\begin{tabular}{|c|c|c|c|c|c|c|c|c|c|}
\hline \multirow{2}{*}{ Polymorphism } & \multirow{2}{*}{ Contrast } & \multicolumn{2}{|c|}{ No. of studies } & \multicolumn{2}{|c|}{ No. of cases } & \multicolumn{2}{|c|}{ No. of controls } & \multicolumn{2}{|c|}{ Overall results } \\
\hline & & previous & present & previous & present & previous & present & previous & present \\
\hline$+936 \mathrm{C} / \mathrm{T}$ & TT vs. CC & 3 & 6 & 407 & 1,445 & 621 & 2,337 & - & + \\
\hline \multirow[t]{4}{*}{ (rs3025039) } & TT vs. $\mathrm{CT}+\mathrm{CC}$ & & & & & & & - & + \\
\hline & $\mathrm{TT}+\mathrm{CT}$ vs. $\mathrm{CC}$ & & & & & & & - & + \\
\hline & CT vs. CC & & & & & & & - & - \\
\hline & T vs. C & & & & & & & - & + \\
\hline$-2578 \mathrm{C} / \mathrm{A}$ & AA vs. CC & 2 & 5 & 359 & 1,397 & 378 & 2,094 & + & + \\
\hline \multirow[t]{4}{*}{ (rs699947) } & $\mathrm{AA}$ vs. $\mathrm{CA}+\mathrm{CC}$ & & & & & & & - & + \\
\hline & $\mathrm{AA}+\mathrm{CA}$ vs. $\mathrm{CC}$ & & & & & & & - & + \\
\hline & CA vs. CC & & & & & & & - & + \\
\hline & A vs. C & & & & & & & + & + \\
\hline$+1612 \mathrm{G} / \mathrm{A}$ & AA vs. GG & NA & 3 & NA & 918 & NA & 1,330 & NA & - \\
\hline \multirow[t]{4}{*}{ (rs10434) } & AA vs. GA+GG & & & & & & & NA & - \\
\hline & $\mathrm{AA}+\mathrm{GA}$ vs. GG & & & & & & & NA & - \\
\hline & GA vs. GG & & & & & & & NA & - \\
\hline & A vs. $G$ & & & & & & & NA & - \\
\hline$-460 \mathrm{~T} / \mathrm{C}$ & CC vs. TT & 2 & 3 & 265 & 677 & 475 & 1,299 & - & - \\
\hline \multirow[t]{4}{*}{ (rs833061) } & $\mathrm{CC}$ vs. TC+TT & & & & & & & - & - \\
\hline & $\mathrm{CC}+\mathrm{TC}$ vs. TT & & & & & & & - & - \\
\hline & TC vs. TT & & & & & & & - & - \\
\hline & C vs. T & & & & & & & - & - \\
\hline$-634 \mathrm{G} / \mathrm{C}$ & CC vs. GG & NA & 3 & NA & 1,038 & NA & 1,716 & NA & - \\
\hline \multirow[t]{4}{*}{ (rs2010963) } & $\mathrm{CC}$ vs. $\mathrm{GC}+\mathrm{GG}$ & & & & & & & NA & - \\
\hline & $\mathrm{CC}+\mathrm{GC}$ vs. $\mathrm{GG}$ & & & & & & & NA & - \\
\hline & GC vs. GG & & & & & & & NA & - \\
\hline & C vs. G & & & & & & & NA & - \\
\hline$-405 \mathrm{G} / \mathrm{C}$ & CC vs. GG & 2 & 2 & 262 & 262 & 477 & 477 & - & - \\
\hline \multirow[t]{4}{*}{ (rs2010963) } & $\mathrm{CC}$ vs. $\mathrm{GC}+\mathrm{GG}$ & & & & & & & - & - \\
\hline & $\mathrm{CC}+\mathrm{GC}$ vs. GG & & & & & & & - & - \\
\hline & GC vs. GG & & & & & & & - & - \\
\hline & C vs. G & & & & & & & - & - \\
\hline$-1154 \mathrm{G} / \mathrm{A}$ & AA vs. GG & 2 & 2 & 373 & 373 & 516 & 516 & - & - \\
\hline \multirow[t]{4}{*}{ (rs1570360) } & AA vs. GA+GG & & & & & & & - & - \\
\hline & $\mathrm{AA}+\mathrm{GA}$ vs. GG & & & & & & & - & - \\
\hline & GA vs. GG & & & & & & & - & - \\
\hline & A vs. G & & & & & & & - & - \\
\hline
\end{tabular}




\section{MATERIALS AND METHODS}

\section{Search strategy and selection criteria}

According to the Preferred Reporting Items for Systematic Reviews and Meta-Analyses (PRISMA), we performed an electronic systematic search of PubMed, the Cochrane Library database, EMBASE, Google Scholar and the China National Knowledge Infrastructure (CNKI) without any restriction on language up to June 5, 2016. The combinations of keywords used were "renal cancer" or "renal carcinoma"; "polymorphism" or "variant"; and "vascular endothelial growth factor" or "VEGF." In addition, the reference lists of the papers retrieved and recent reviews were also examined. We included all studies that (1) evaluated the association between VEGF polymorphisms and the risk of RCC in humans; (2) used a case control design; (3) confirmed RCC using the accepted diagnostic criteria; (4) reported sufficient published data, including ORs and their $95 \%$ CIs, or the number of events for the purposes of calculation. The exclusion criteria were (1) a lack of sufficient data to calculate ORs with corresponding 95\% CIs; and (2) overlapping cases or controls. Only the most recent or the largest research study was included in the case of overlap.

\section{Data extraction}

Two investigators (GMC and DWJ) extracted the raw data independently based on the inclusion and exclusion criteria. The following information was extracted from all of the enrolled studies (see Table 1): the surname of the first author, date of publication, participant ethnicity, quality scores, sources of controls, number of cases and controls and the HWE $P$-value. All disagreements were resolved via discussion.

\section{Quality assessment}

Two authors (GMC and SZR) assessed the study quality using the NOS [36] which evaluates methodological quality using a star rating system. Nine stars was defined as a full score; 5 to 9 stars was considered as being of high methodological quality; and 0 to 4 stars was considered as being of poor quality [37]. The quality of all the included studies is listed in Table 2. For conflicting NOS scores, an agreement was reached via a comprehensive reassessment, and only high-quality studies were included in our meta-analysis.

\section{Statistical analysis}

The relationship between $V E G F$ polymorphisms and the risk of RCC was evaluated via pooled ORs with 95\% CIs. The significance of the pooled ORs was tested using the $Z$-test, and a (two-tailed) $P$-value of $<0.05$ was regarded as significant. The HWE was calculated in the control groups using the chi-square test, and $P<0.05$ signified a departure from HWE. Betweenstudy heterogeneity was calculated using the $I^{2}$ test. If the heterogeneity was significant $\left(I^{2}>50 \%\right)$ [38], then a random-effects model was used (the DerSimonian and Laird method) [39]; otherwise, the fixed-effect model (the Mantel-Haenszel method) [40] was applied. To assess the stability of the results, sensitivity analyses were conducted to evaluate the impact of the studies, especially which not in HWE. Because publication bias is always a concern for meta-analyses, funnel plots and Egger's test were both used to examine publication bias $(P<0.05$ was considered as significant publication bias) [41]. All statistical analyses were performed using STATA statistical software (Version 12.0; Stata Corporation, College Station, TX, USA).

\section{CONFLICTS OF INTEREST}

The authors declare no potential conflicts of interest.

\section{GRANT SUPPORT}

This research was supported by the Science and Technology Plan Project of Zhongshan City (2015B1012), medical research foundation of Guangdong province (A2016058) and medical research foundation of Zhongshan City (2016J040).

\section{REFERENCES}

1. GLOBOCAN. Estimated cancer incidence, mortality and prevalence worldwide in 2012. International Agency for Research on Cancer. 2012; Available: http://globocan.iarc. fr/Pages/fact_sheets_population.aspx.

2. Rini BI, Campbell SC, Escudier B. Renal cell carcinoma. Lancet. 2009; 373: 1119-32. doi: 10.1016/ S0140-6736(09)60229-4.

3. Bjørge T, Tretli S, Engeland A. Relation of height and body mass index to renal cell carcinoma in two million Norwegian men and women. Am J Epidemiol. 2004; 160: 1168-76. doi: 10.1093/aje/kwh345.

4. Hunt JD, van der Hel OL, McMillan GP, Boffetta P, Brennan P. Renal cell carcinoma in relation to cigarette smoking: meta-analysis of 24 studies. In J Cancer. 2005; 114: 101-8. doi: 10.1002/ijc.20618.

5. Vineis P, Alavanja M, Buffler P, Fontham E, Franceschi S, Gao YT, Gupta PC, Hackshaw A, Matos E, Samet J, Sitas F, Smith J, Stayner L, et al. Tobacco and cancer: recent epidemiological evidence. Natl Cancer Inst. 2004; 96: 99-106. doi: 10.1093/jnci/djh014.

6. Bellocco R, Pasquali E, Rota M, Bagnardi V, Tramacere I, Scotti L, Pelucchi C, Boffetta P, Corrao G, La Vecchia C. Alcohol drinking and risk of renal cell carcinoma: results of a meta-analysis. Ann Oncol. 2012; 23: 2235-44. doi: 10.1093/annonc/mds022. 
7. Adams KF, Leitzmann MF, Albanes D, Kipnis V, Moore $\mathrm{SC}$, Chow WH. Body size and renal cell cancer incidence in a large US cohort study. Am J Epidemiol. 2008; 168: 26877. doi: 10.1093/aje/kwn122.

8. Mu HJ, Zou J, Xie P, Xu ZQ, Ruan J, Yang SD, Yin Y. Association of leptin receptor Lys109Arg and Gln223Arg polymorphisms with increased risk of clear cell renal cell carcinoma. Asian Pac J Cancer Prev. 2014; 15: 4211-5.

9. Atilgan D, Parlaktas BS, Uluocak N, Kolukcu E, Erdemir F, Ozyurt H, Erkorkmaz U. The relationship between ALA16VAL single gene polymorphism and renal cell carcinoma. Adv Urol. 2014; 2014: 932481. doi: $10.1155 / 2014 / 932481$.

10. Motzer RJ, Hutson TE, Tomczak P, Michaelson MD, Bukowski RM, Rixe O, Oudard S, Negrier S, Szczylik C, Kim ST, Chen I, Bycott PW, Baum CM, et al. Sunitinib versus interferon alfa in metastatic renal-cell carcinoma. $\mathrm{N}$ Engl J Med. 2007; 356: 115-24. doi: 10.1056/ NEJMoa065044

11. Patard JJ, Pouessel D, Bensalah K, Culine S. Targeted therapy in renal cell carcinoma. World J Urol. 2008; 26: 135-40. doi: 10.1007/s00345-008-0237-4.

12. Evensen L, Micklem DR, Blois A, Berge SV, Aarsaether N, Littlewood-Evans A, Wood J, Lorens JB. Mural cell associated VEGF is required for organotypic vessel formation. PLoS One. 2009; 4: e5798. doi: 10.1371/journal.pone.0005798.

13. Andersen S, Donnem T, Al-Shibli K, Al-Saad S, Stenvold $\mathrm{H}$, Busund LT, Bremnes RM. Prognostic impacts of angiopoietins in NSCLC tumor cells and stroma: VEGF-A impact is strongly associated with Ang-2. PLoS One. 2011; 6: e19773. doi: 10.1371/journal.pone.0019773.

14. Watson CJ, Webb NJ, Bottomley MJ, Brenchley PE. Identification of polymorphisms within the vascular endothelial growth factor (VEGF) gene: correlation with variation in VEGF protein production. Cytokine. 2000; 12: 1232-5. doi:10.1006/cyto.2000.0692.

15. Ruggiero D, Dalmasso C, Nutile T, Sorice R, Dionisi L, Aversano M, Bröet P, Leutenegger AL, Bourgain C, Ciullo M. Genetics of VEGF serum variation in human isolated populations of cilento: importance of VEGF polymorphisms. PLoS One. 2011; 6: e16982. doi: 10.1371/ journal.pone.0016982.

16. Kawai Y, Sakano S, Korenaga Y, Eguchi S, Naito K. Associations of single nucleotide polymorphisms in the vascular endothelial growth factor gene with the characteristics and prognosis of renal cell carcinomas. Eur Urol. 2007; 52: 1147-55. doi: 10.1016/j.eururo.2007.01.073.

17. Abe A, Sato K, Habuchi T, Wang L, Li Z, Tsuchiya N, Ohyama C, Satoh S, Ogawa O, Kato T. Single nucleotide polymorphisms in the $3^{\prime}$ untranslated region of vascular endothelial growth factor gene in Japanese population with or without renal cell carcinoma. Tohoku J Exp Med. 2002; 198: 181-90. doi: 10.1620/tjem.198.181.
18. Bruyère $\mathrm{F}$, Hovens $\mathrm{CM}$, Marson $\mathrm{MN}$, d'Arcier $\mathrm{BF}$, Costello AJ, Watier H, Linassier C, Ohresser M. VEGF polymorphisms are associated with an increasing risk of developing renal cell carcinoma. J Urol. 2010; 184: 1273-8. doi: 10.1016/j.juro.2010.06.009.

19. Sáenz-López P, Vazquez F, Cozar JM, Carretero R, Garrido F, Ruiz-Cabello F. VEGF polymorphisms are not associated with an increased risk of developing renal cell carcinoma in Spanish population. Hum Immunol. 2013; 74: 98-103. doi: 10.1016/j.humimm.2012.10.014.

20. Shen BL, Qu QS, Miao SZ, Zhang YX. Association between SNPs in vascular endothelial growth factor polymorphisms and risk of renal cell carcinoma: a case-control study. Genet Mol Res. 2015; 14: 11119-25. doi: 10.4238/2015. September.22.5.

21. Lu G, Dong Y, Zhang Q, Jiao L, Yang S, Shen B. Predictive value of vascular endothelial growth factor polymorphisms on the risk of renal cell carcinomas: a case-control study. Tumour Biol. 2015; 36: 8645-52. doi: 10.1007/ s13277-015-3431-1.

22. Xian $\mathrm{W}$, Zheng $\mathrm{H}, \mathrm{Wu}$ WJ. Predictive value of vascular endothelial growth factor polymorphisms on the risk of renal cell carcinomas. Genet Mol Res. 2015; 14: 7634-42. doi: 10.4238/2015.July.13.8.

23. Ajaz S, Khaliq S, Abid A, Hassan AS, Hashmi A, Sultan G, Mohsin R, Mubarrak M, Naqvi SA, Rizvi SA, Mehdi $\mathrm{SQ}$. Association of a single-nucleotide polymorphism in the promoter region of the VEGF gene with the risk of renal cell carcinoma. Genet Test Mol Biomarkers. 2011; 15: 6537. doi: 10.1089/gtmb.2011.0029.

24. Ricketts C, Zeegers MP, Lubinski J, Maher ER. Analysis of germline variants in CDH1, IGFBP3, MMP1, MMP3, STK15 and VEGF in familial and sporadic renal cell carcinoma. PLoS One. 2009; 4: e6037. doi: 10.1371/ journal.pone.0006037.

25. Kushner EJ, Bautch VL. Building blood vessels in development and disease. Curr Opin Hematol. 2013; 20: 231-6. doi: 10.1097/MOH.0b013e328360614b.

26. Jacobsen J, Rasmuson T, Grankvist K, Ljungberg B. Vascular endothelial growth factor as prognostic factor in renal cell carcinoma. J Urol. 2000; 163: 343-7. doi: 10.1016/S0022-5347(05)68049-4.

27. Lee JS, Kim HS, Jung JJ, Park CS, Lee MC. Expression of vascular endothelial growth factor in renal cell carcinoma and the relation to angiogenesis and p53 protein expression. J Surg Oncol. 2001; 77: 55-60. doi: 10.1002/jso.1066

28. Albiges L, Salem M, Rini B, Escudier B. Vascular endothelial growth factor-targeted therapies in advanced renal cell carcinoma. Hematol Oncol Clin North Am. 2011; 25: 813-33. doi: 10.1016/j.hoc.2011.04.006.

29. J Jakubowska A, Gronwald J, Menkiszak J, Górski B, Huzarski T, Byrski T, Edler L, Lubiński J, Scott RJ, Hamann U. The VEGF_936_C $>$ T 3'UTR polymorphism 
reduces BRCA1-associated breastcancer risk in Polish women. Cancer Lett. 2008; 262: 71-6. doi: 10.1016/j. canlet.2007.11.029.

30. Zhang Y, Li S, Xiao HQ, Hu ZX, Xu YC, Huang Q. Vascular endothelial growth factor gene polymorphisms and renal cell carcinoma: A systematic review and metaanalysis. Oncol Lett. 2013; 6: 1068-78. doi: 10.3892/ ol.2013.1499.

31. Renner W, Kotschan S, Hoffmann C, Obermayer-Pietsch $\mathrm{B}$, Pilger E. A common $936 \mathrm{C} / \mathrm{T}$ mutation in the gene for vascular endothelial growth factor is associated with vascular endothelial growth factor plasma levels. J Vasc Res.2000; 37: 443-8. doi: 10.1159/000054076.

32. Krippl P, Langsenlehner U, Renner W, Yazdani-Biuki B, Wolf G, Wascher TC, Paulweber B, Haas J, Samonigg $\mathrm{H}$. A common $936 \mathrm{C} / \mathrm{T}$ gene polymorphism of vascular endothelial growth factor is associated with decreased breast cancer risk. Int J Cancer. 2003; 106: 468-71. doi: 10.1002/ijc. 11238 .

33. Hsieh JJ, Manley BJ, Khan N, Gao J, Carlo MI, Cheng EH. Overcome tumor heterogeneity-imposed therapeutic barriers through convergent genomic biomarker discovery: A braided cancer river model of kidney cancer. Semin Cell Dev Biol. 2016; pii: S1084-9521(16)30286-5. doi: 10.1016/j.semcdb.2016.09.002.

34. Balasubramanian SP, Brown NJ, Reed MW. Role of genetic polymorphisms in tumour angiogenesis. Br J Cancer. 2002; 87: 1057-65. doi: 10.1038/sj.bjc.6600625.
35. Stathopoulou MG, Bonnefond A, Ndiaye NC, AzimiNezhad M, El Shamieh S, Saleh A, Rancier M, Siest G, Lamont J, Fitzgerald P, Visvikis-Siest S. A common variant highly associated with plasma VEGFA levels also contributes to the variation of both LDL-C and HDL-C. J Lipid Res. 2013; 54: 535-41. doi: 10.1194/jlr.P030551.

36. GA Wells, B Shea, D O'Connell, J Peterson, V Welch, M Losos, et al. The Newcastle-Ottawa Scale (NOS) for assessing the quality of nonrandomised studies in the metaanalysis. Available: http://www.ohri.ca/programs/clinical_ epidemiology/oxford.asp.

37. Ownby RL, Crocco E, Acevedo A, John V, Loewenstein D. Depression and risk for Alzheimer disease:systematic review, meta-analysis. Arch Gen Psychiatry. 2006; 63: 5308. doi: 10.1001/archpsyc.63.5.530.

38. Higgins JP, Thompson SG, Deeks JJ, Altman DG. Measuring inconsistency in meta-analyses. BMJ. 2003; 327 : 557-60. doi: 10.1136/bmj.327.7414.557.

39. DerSimonian R, Laird N. Meta-analysis in clinical trials. Control Clini Trials. 1986; 7: 177-88. doi: 10.1016/0197-2456(86)90046-2.

40. Mantel N, Haenszel W. Statistical aspects of the analysis of data from retrospective studies of disease. J Natl Cancer Inst. 1959; 22: 719-48. doi: 10.1016/0021-9681(79)90031-6.

41. Egger M, Davey Smith G, Schneider M, Minder C. Bias in meta-analysis detected by a simple, graphical test. Br Med J. 1997; 315: 629-34. doi: 10.1136/bmj.315.7109.629. 